\title{
Labidocera species (Copepoda: Pontellidae) in Indonesian waters with notes on their species-groups
}

\author{
Mulyadi M ulyadi* \\ Division of Zoology, Research Center for Biology, Indonesian Institute of Sciences
}

\begin{abstract}
Thirteen species of the genus Labidocera L ubbock, 1853 were identified. Plankton samples collected from nine sites around coastal areas of Indonesia from 2003 to 2015. A mong these species, there were three recently described species, Labidocera javaensis M ulyadi, 1997, L. muranoi M ulyadi, 1997, and L. kaimanaensis Mulyadi, 2014, three new records, L. bengalensis Krishnaswamy, 1952, L. pavo Giesbrecht, 1889 and $L$. sinilobata Shen \& Lee, 1963, and seven previously recorded species from Indonesian waters. These species divided into five species-groups, detruncata-, kroyeri-, minuta-, pectinata- and an unassigned group, based on its morphological characters. The Labidocera detruncata-group includes the following species: L. bataviae A . Scott, 1909, L. detruncata (Dana, 1849), L. kaimanaensis Mulyadi, 2014, L. madurae A. Scott, 1909, L. pavo Giesbrecht, 1889, and L. sinilobata Shen \& Lee, 1963. The Labidocera kroyeri-group includes L. kroyeri (B rady, 1883) and L. muranoi Mulyadi, 1997. The Labidocera minuta-group includes L. bengalensis K rishnaswamy, 1952 and L. minuta Giesbrecht, 1889. The Labidocera pectinata-group includes L. javaensis M ulyadi, 1997, L. papuensis Fleminger et al. 1982, and L. rotunda M ori, 1929. The unassigned group includes L. acuta (Dana, 1849) and L. laevidentata (Brady, 1883). Since the descriptions of these species groups and also species as yet unassigned to groups were often not given in sufficient detail, we provide re-descriptions of their species groups and their zoogeography in Indonesian waters, adjacent waters, and the world oceans
\end{abstract}

\section{Introduction}

The genus Labidocera was established by Lubbock [1] for the species L. darwini Lubbock, 1853, collected from off Argentina. The genus is the largest in the family Pontellidae, currently accommodating 60 valid species [2], the majority of them distributed in Indo-Pacific region. Most Labidocera species restricted to waters ranging from warm-temperate to tropical. The biogeographical distribution of the genus is intriguing and used as a biological indicator of water masses, inshore-offshore boundaries, and divisions between zoogeographical regions [3-6].

Most members of the genus Labidocera are found at day and night in the surface layer usually beneath the neuston, to a depth of about 10-15 m. In Indonesian waters, 15 species of Labidocera already reported [4, 711]. These species divided into five species-groups based on morphological characteristics, i.e., L. detruncata, $L$. kroyeri, L. minuta, L. pectinata, and an unnamed group $[3,4,8,10]$.

In this study, were described 13 species from five species groups of Labidocera collected from nine sites around Indonesian coastal waters. The text further aims at clarifying some synonymy and discusses the distribution of these species and their species-groups here reported upon, in Indonesian waters, in adjacent waters and throughout the world's oceans.

\section{Material and methods}

Plankton samples collected from nine sites around coastal areas of Indonesia from 1998 to 2015. Sampling did by the author, which included surface towing and vertical hauls. Vertical towing was carried out from $10-$ $25 \mathrm{~m}$ depth to the surface with a conical plankton net $(0.33 \mathrm{~mm}$ mesh size and $0.45 \mathrm{~mm}$ diameter mouth aperture) at day and night time.

For the convenience of description, these sites divided into three study areas with the consideration of their topography and hydrological conditions. They were the coastal waters of the Java Sea (Area A includes Sites 1, 2 and 3), Indian Seaside of southern Java (Area B includes Sites 4, 5 and 6), and the eastern region (Area C includes Sites 7, 8 and 9). Samples were fixed and preserved in $5 \%$ buffered formaldehyde/seawater solution. Specimens of Labidocera sorted from the original samples, stained with methylene blue, appendages dissected with needles in $10 \%$ glycerol/distilled water solution, and observation done under a compound microscope equipped with a drawing tube. The morphological terminology used here follows [12]

\footnotetext{
*Corresponding author: muly010@lipi.go.id
} 
Table 1. Sampling sites, dates and number of samples in Indonesian waters.

\begin{tabular}{|c|c|c|c|c|}
\hline No & $\begin{array}{c}\text { Sites } \\
\text { Position }\end{array}$ & Date & Depth of hauls & $\begin{array}{c}\begin{array}{c}\text { Number of } \\
\text { samples }\end{array} \\
\end{array}$ \\
\hline 1 & $\begin{array}{l}\text { Jakarta B ay } \\
\left(06^{\circ} 00^{\prime} \mathrm{S} 106^{\circ} 45^{\prime} \mathrm{E}\right)\end{array}$ & $\begin{array}{l}\text { 28-31 A ugt.2008, } \\
20 \text { Sept. } 2011\end{array}$ & $10-25 \mathrm{~m}$ & 10 \\
\hline 2 & $\begin{array}{l}\text { Off Tegal, Central Java } \\
\left(06^{\circ} 00^{\prime} \mathrm{S} 109^{\circ} 10^{\prime} \mathrm{E}\right)\end{array}$ & $23 \mathrm{M}$ arch 2006 & $5-15 m$ & 10 \\
\hline 3 & $\begin{array}{l}\text { Off Surabaya, East Java } \\
\left(07^{\circ} 10^{\prime} \mathrm{S} 109^{\circ} 10^{\prime} \mathrm{E}\right)\end{array}$ & $\begin{array}{c}10 \text { October } 2010 \\
13 \text { J uly } 2012\end{array}$ & $10-20 \mathrm{~m}$ & 10 \\
\hline 4 & $\begin{array}{l}\text { Off Sendangbiru, East J ava } \\
\left(08^{\circ} 26^{\prime} 24^{\prime \prime} \mathrm{S} 112^{\circ} 41^{\prime} 45^{\prime \prime} \mathrm{E}\right)\end{array}$ & $\begin{array}{l}29 \text { J une } 2006 \\
26 \text { June } 2010\end{array}$ & $10-25 \mathrm{~m}$ & 10 \\
\hline 5 & $\begin{array}{l}\text { Cilacap B ay, Central J ava } \\
\left(07^{\circ} 40^{\prime} \mathrm{S} 109^{\circ} 00^{\prime} \mathrm{E}\right)\end{array}$ & $\begin{array}{c}24 \mathrm{M} \text { arch 2008, } \\
1-4 \mathrm{M} \text { ay } 2009\end{array}$ & $10-25 \mathrm{~m}$ & 10 \\
\hline 6 & $\begin{array}{l}\text { Panaitan Island, Banten } \\
\left(07^{\circ} 40^{\prime} \mathrm{S} 109^{\circ} 00^{\prime} \mathrm{E}\right)\end{array}$ & 5-7 Nov. 2008 & $10-25 \mathrm{~m}$ & 10 \\
\hline 7 & $\begin{array}{l}\text { Lombok Strait, NTB } \\
\left(08^{\circ} 40^{\prime} \mathrm{S} 116^{\circ} 10^{\prime} \mathrm{E}\right.\end{array}$ & 25-27 A pril 2015 & $10-25 \mathrm{~m}$ & 10 \\
\hline 8 & $\begin{array}{l}\text { Bitung B ay, North Sulawesi } \\
1^{\circ} 25^{\prime} 60^{\prime \prime} \mathrm{N}, 125^{\circ} 10^{\prime} 60^{\prime \prime} \mathrm{E}\end{array}$ & $\begin{array}{c}20-25 \text { J une } 2003, \\
14-18 \text { Mei } 2004\end{array}$ & $10-25 \mathrm{~m}$ & 10 \\
\hline 9 & $\begin{array}{l}\text { Arguni Bay, West Papua } \\
\left(32^{\circ} 21.9^{\prime} \mathrm{S} 133^{\circ} 53^{\prime} 11^{\prime \prime} \mathrm{E}\right)\end{array}$ & 29 Oct.-9 N ov. 2010 & $10-25 \mathrm{~m}$ & 10 \\
\hline
\end{tabular}

Abbreviation used in the description are: A1, antennule; A2, antenna; Pdg1-Pdg5, pedigerous somites 1-5; P1-P5, swimming legs 1-5; Ur1-Ur5, urosomal somites $1-5$; CR, caudal ramus $/ \mathrm{i}$; $\mathrm{CO}$, coxa, $\mathrm{BA}$, basis; Re1-Re3, exopodal segments 1-3; Ri1-Ri3, endopodal segments 1-3; Se, outer spine; $\mathrm{Si}$, inner spine; St, terminal spine. The prosome length measured from the anterior apex to the mid-posterior end of the prosome, and the urosome length from the mid-anterior end of urosome to the posterior end of the caudal rami.

All type-specimens are formalin-preserved and deposited at the Museum Zoologicum Bogoriense (MZB), Research Center for Biology, Indonesian Institute of Sciences (LIPI), Cibinong, Indonesia.

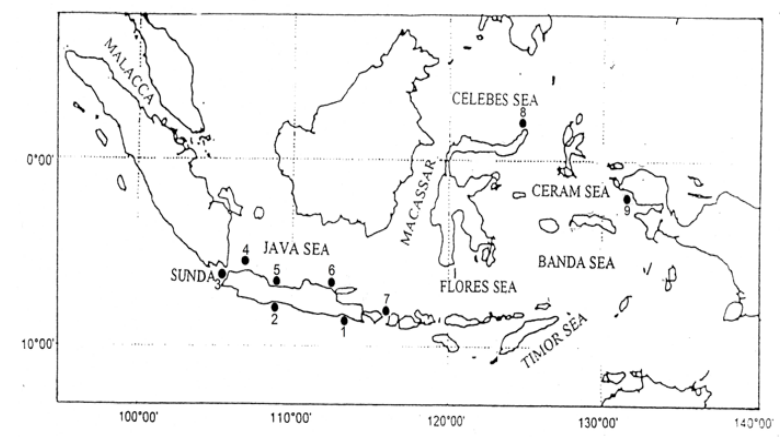

Fig. 1. M ap of Indonesia and sampling sites 1- 9

\section{Result and discussion}

A total of 13 species of Labidocera were identified (Table 2). Among these species, three recently described species, i.e., L. javaensis, $L$. muranoi, and $L$. kaimanaensis, three new records, $L$. bengalensis, $L$. pavo, and L. sinilobata, and seven previously recorded species, L. acuta, L. bataviae, L. detruncata, L. kröyeri, L. laevidentata, L. madurae, and L. minuta. The number of observed species was highest at the eastern part (Area C) with 11 recorded species, in which seven species occurred in Site 7 (Lombok Strait). The Labidocera species records decreased toward the coastal areas of the Java Sea and Indian Seaside (Areas A and B) with 8 and 6 species, respectively.

Among the Labidocera species discovered in this study, five species (L. acuta, L. kroyeri, L. laevidentata, L. minuta and L. pavo) distributed in all study areas (Areas A-B-C), two species (L. bengalensis and $L$. javaensis) are in Area A-C, one species (L. sinilobata) is only in Area A, one species (L. muranoi) is only in Area $\mathrm{B}$, and four species (L. bataviae, L. detruncata, $L$. kaimanaensis, and L. madurae) are only in Area C, respectively (Table 2).

The occurrence, geographic ranges, and habitats of all recorded species listed in Table 2. Of these species, one species, L. detruncata $(7.7 \%)$ was cosmopolitan, while Indo-Pacific species comprised seven species $(53.8 \%)$ of the total species number. Only one species (7.7\%) each found from either Indian or Pacific Oceans in this study, L. bengalensis and L. sinilobata, respectively. The remaining three species (23.1\%) appear to be endemic to Indonesian waters.

Based on their horizontal distribution and habitats, copepods divided into five groups, oceanic, neriticoceanic, neritic, estuarine-neritic and estuarine [13-14]. According to these groups, $84.62 \%$ (11 species) of the present species classified as neritic species, and $15.38 \%$ (two species L. acuta and L. laevidentata) were neriticoceanic species. 
Table 2. Species of Labidocera recorded in the present study, their distribution in the adjacent and Indonesian waters and the major oceans $(\mathrm{A}=$ Indonesian waters, $\mathrm{B}=$ Malaysian waters, $\mathrm{C}=$ China Seas, $\mathrm{D}=$ Australian waters, $\mathrm{I}=$ the Indian Ocean, $\mathrm{P}=\mathrm{Pacific}$ Ocean, $\mathrm{At}=$ the Atlantic Ocean), $\mathrm{N}-\mathrm{O}=$ neritic-oceanic, $\mathrm{N}=$ neritic. $\mathrm{o}=$ present records, $\bullet=$ previous records, $\boldsymbol{\Delta}=$ endemic for Indonesian waters, $\Delta=$ new records.

Sources of data for the Southeast Asian and Australian areas: A = A. Scott (1909); Fleminger et al. (1982); Mulyadi (1997, 2002, 2014). $\mathrm{B}=$ Othman \& Toda (2004); C = Chen \& Zhang (1965); Chen \& Shen (1974); D = Brady (1883); Farran (1936, 1949); Greenwood (1978, 1979); Dakin \& Colefax (1940); Nicholls (1944); Othman et al. (1990).

Sources of data for major oceanic areas: I = Sewell (1932); Krishnaswamy (1952); Silas \& Pillai (1973). P = Mori (1937); Tanaka (1964); Marumo \& Matsuo (1962); Sherman (1963, 1964). At = Giesbrecht (1892); T. Scott (1894); Owre \& Foyo (1967).

\begin{tabular}{|c|c|c|c|c|c|c|c|c|c|c|c|c|c|c|c|}
\hline \multirow[b]{2}{*}{ Species } & \multicolumn{9}{|c|}{ Sites } & \multicolumn{4}{|c|}{ Adjacent areas } & \multicolumn{2}{|c|}{ Remarks } \\
\hline & 1 & 2 & 3 & 4 & 5 & 6 & 7 & 8 & 9 & A & $\mathrm{B}$ & $\mathbf{C}$ & $\mathrm{D}$ & Oceans & Habitat \\
\hline L. acuta & $\mathrm{o}$ & & $\mathrm{o}$ & o & o & $\mathrm{o}$ & o & o & $\mathrm{o}$ & - & - & - & - & I-P & $\mathrm{N}-\mathrm{O}$ \\
\hline L. bataviae & & & & & & & o & o & $\mathrm{o}$ & - & & & & I-P & $\mathrm{N}$ \\
\hline L. bengalensis & o & o & o & & & & o & & & $\Delta$ & & & & I & $\mathrm{N}$ \\
\hline L. detruncata & & & & & & & o & & & $\bullet$ & & - & - & I-P-At & $\mathrm{N}$ \\
\hline L. javaensis & o & o & $\mathrm{o}$ & & & & o & & & $\Delta$ & & & & & $\mathrm{N}$ \\
\hline L. kaimanaensis & & & & & & & & & $\mathrm{o}$ & $\Delta$ & & & & & $\mathrm{N}$ \\
\hline L. kroyeri & & o & o & & & o & & o & & $\bullet$ & $\bullet$ & $\bullet$ & & I-P & $\mathrm{N}$ \\
\hline L. laevidentata & & & o & & & o & & o & & $\bullet$ & $\bullet$ & & - & I-P & $\mathrm{N}-\mathrm{O}$ \\
\hline L. madurae & & & & & & & & o & & $\bullet$ & & & & I-P & $\mathrm{N}$ \\
\hline L. minuta & $\mathrm{o}$ & o & $\mathrm{o}$ & 0 & 0 & $\mathrm{o}$ & $\mathrm{o}$ & o & $\mathrm{o}$ & $\bullet$ & $\bullet$ & $\bullet$ & - & I-P & $\mathrm{N}$ \\
\hline L. muranoi & & & & o & o & & & & & $\Delta$ & $\bullet$ & & & & $\mathrm{N}$ \\
\hline L. pavo & o & o & o & o & & o & o & & & $\Delta$ & $\bullet$ & - & & I-P & $\mathrm{N}$ \\
\hline L. sinilobata & 0 & o & o & & & & & & & $\Delta$ & & $\bullet$ & & China & $\mathrm{N}$ \\
\hline $\begin{array}{l}\text { Total number of } \\
\text { species }\end{array}$ & 6 & 6 & 8 & 4 & 3 & 5 & 7 & 6 & 4 & & & & & & \\
\hline
\end{tabular}

The species of Labidocera comprise a somewhat heterogeneous assemblage. So far, no complete review of the group based on the study of species from all the world that has made, and a minimal attempt has never made to separate the groups of related species. It will be shown that there are several different groups of species each with a number of important features in common, which tend to constitute morphologically and also zoogeographically distinct groups. In the genus Labidocera, species and species groups distinguished by the structure of the last pedigerous somite, the genital compound somite, caudal rami, rostrum, and $5^{\text {th }}$ legs of both sexes $[4,8,10]$. All the Indonesian recorded species of Labidocera divided into five species-groups, namely L. detruncata, L. kroyeri, L. minuta, L. pectinata and unassigned group.

\section{Zoogeography of Labidocera species and species-groups}

Ideally, the species-group consists of all extant species of a distinct lineage within the genus; the member species are morphologically and adaptationally similar, their geographical range allopatric or parapatric and relatively short. Thus, plankton copepod species groups are promising subjects for investigating questions concerned with the evolution and causal biogeography in the pelagic biotope [3, 4]
Mulyadi [9] was the first who define the Indo-West Pacific group within the $L$. detruncata species complex, which he referred to $L$. detruncata species group. The $L$. detruncata group comprises 16 species. Labidocera detruncata distributed over the entire tropical and subtropical Indian, Pacific and Atlantic Oceans, whereas nine species (L. bataviae A. Scott, 1909, L. churaumi Hirabayashi \& Ohtsuka, 2014, L. detruncata (Dana, 1849), L. jaafari Othman, 1986, L. gangetica Sewell, 1934, L. kaimanaensis Mulyadi, 2014, L. madurae A. Scott, 1909, L. pavo Giesbrecht, 1889, and L. sinilobata Shen \& Lee, 1963) are distributed in the tropical/subtropical waters of the Indo-Pacific between $35^{\circ} \mathrm{N}$ and $35^{\circ} \mathrm{S}[9,10,15]$. Labidocera caudata Nicholls, 1944, L. cervi Kramer, 1895, L. farrani Greenwood \& Othman, 1979, and L. tasmanica Taw, 1974 are restricted to Australian waters [16]; L. nerii (Kroyer, 1849) is Atlantic species [17]; whereas L. boxshalli ElSherbiny \& Ueda, 2010, and L. orsinii Giesbrecht, 1889 are recorded from the Red Sea [18-20].

The Labidocera minuta group comprises only two species, L.bengalensis Krishnaswamy, 1952 and $L$. minuta Giesbrecht, 1889. Labidocera bengalensis is found only in the Indian Ocean before this study, while L. minuta is Indo-Pacific species $[9,15,21,22]$

Labidocera javaensis Mulyadi, 1997 belongs to the L. pectinata-group, which hitherto composed of six species: L. carpentariensis Fleminger et al., 1982, L. japonica Mori, 1935, L. papuensis Fleminger et al., 
1982, L. pectinata Thompson \& Scott, 1903, and L. rotunda Mori, 1929. Labidocera japonica was restricted in Japanese waters, L. papuensis was endemic in the Sorong Sea, L. moretoni was in Moreton Bay, eastern Australian waters, and L. carpentariensis in Gulf of Carpentaria and the northern Arafura Sea, L. pectinata in coastal neritic waters of north-east Indian Seas, and $L$. javaensis has distribution ranges from the Java Sea to Lombok Strait (Fig. 3).

Distribution of the L. kroyeri species group restricted to inshore regions of tropical and subtropical areas between $35^{\circ} \mathrm{N}$ and $25^{\circ} \mathrm{S}$ and $70^{\circ} \mathrm{E}$ and $151^{\circ} \mathrm{E}$. Labidocera kroyeri (Brady, 1883) is widely distributed within this area. However, the rest of the group seems to have relatively narrow distribution range, i.e., L. dakini Greenwood, 1978 from eastern Australian waters and Gulf of Carpentaria, L. gallensis Thompson \& Scott, 1903, and L. stylifera Thompson \& Scott, 1903 have only been recorded from the periphery of north-east Indian Sea. Labidocera muranoi Mulyadi, 1997 was collected from Cilacap Bay, a mangrove estuary facing the Indian Ocean, also have a narrow distribution ranges from Cilacap Bay to Sendangbiru Bay with preference to low salinity (Fig. 2).

\section{Taxonomy of Labidocera species groups in Indonesian waters}

The genus Labidocera is distinguished from the other genera of the Pontellidae in having: 1) the cephalosome provided with a pair of subcuticular lenses, with or without lateral cephalic hooks, 2) the rostrum deeply bifurcated with strong filaments, medio-ventral eye protuberant and extending antero-ventral between rostral prongs (lacking a lens), 3) the posterior corners of prosome usually produced into pointed lobes, 4) the A1 23-segmented, 5) the P1-P4 with 3-segmented Re and 2segmented $\mathrm{Ri}, 6)$ the mandible with 3-4 thin curved denticles, 7) the $2^{\text {nd }}$ segment of maxillar basipodite with a long bristles in distal half, 8) the maxilliped 6segmented, with minute distal segment, 9) the urosome 2-3 somites in female, 5-somites in male, 10) the P5 in female uniramous or biramous with 2-segmented basipodite and 1-segmented $\mathrm{Re}$ and $\mathrm{Ri}, \mathrm{Ri}$ often rudimentary, bifurcated or pectinate at the apex, (11) the P5 in male uniramous, 4-segmented, right leg chelate, left leg often with rudimentary Ri, Remakes a forceps.

Fleminger et al. [4] instituted the Labidocera kroyeri species-group for an intrageneric lineage consisting of $L$. dakini Greenwood, 1978, L. gallensis Thompson \& Scott, 1903, L. kroyeri (Brady, 1883), and L. stylifera Thompson \& Scott, 1903. Although they did not define this group, it may characterized by a combination of 1) the male right $\mathrm{A} 1$ in which segment 18 is armed with a single crescented and deticulated ridge on its anterior margin, 2) the male left P5 with the Re2 armed distally with two blunt, lamelliforn structures crowned with tubercles, and 3) the female P5 with the $\mathrm{Ri}$ with bifurcated termination. Labidocera muranoi Mulyadi, 1997 clearly belongs to this species group in having these three characters. However, the inner process of $\mathrm{Ri}$ in the female P5 is located in the middle of its own segment and not in the distal part.

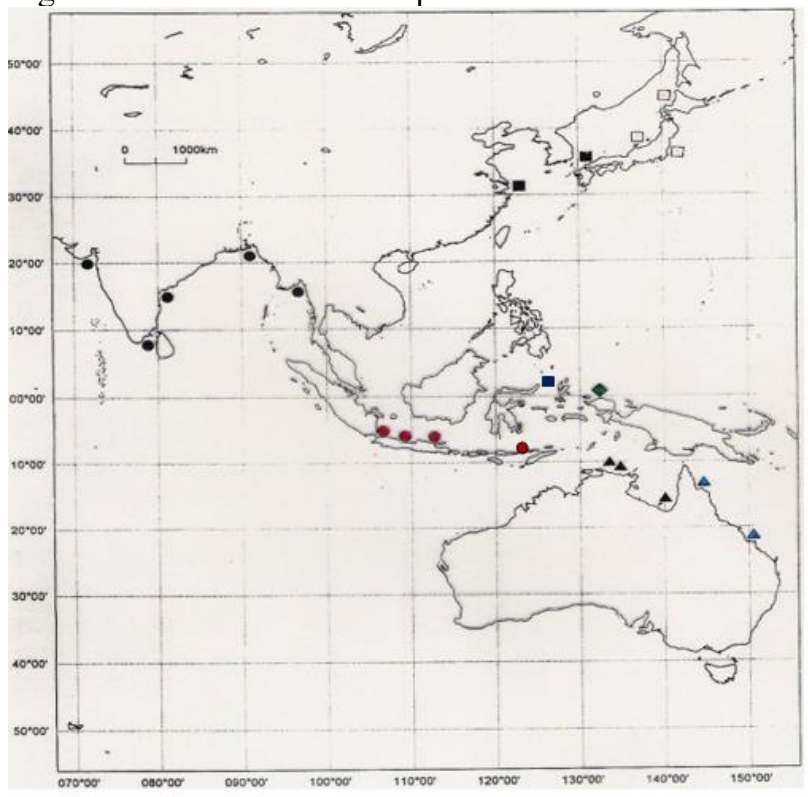

Fig. 2. Distribution of the Labidocerapectinata-group $\bullet=L$. petinata, $0=L$. javaensis, $\square=L$. rotunda, $\square=$ L. japonica, $\boldsymbol{\Delta}=$ L. carpentariensis, $\Delta=$ L. moretoni, $=$ L. papuensis.

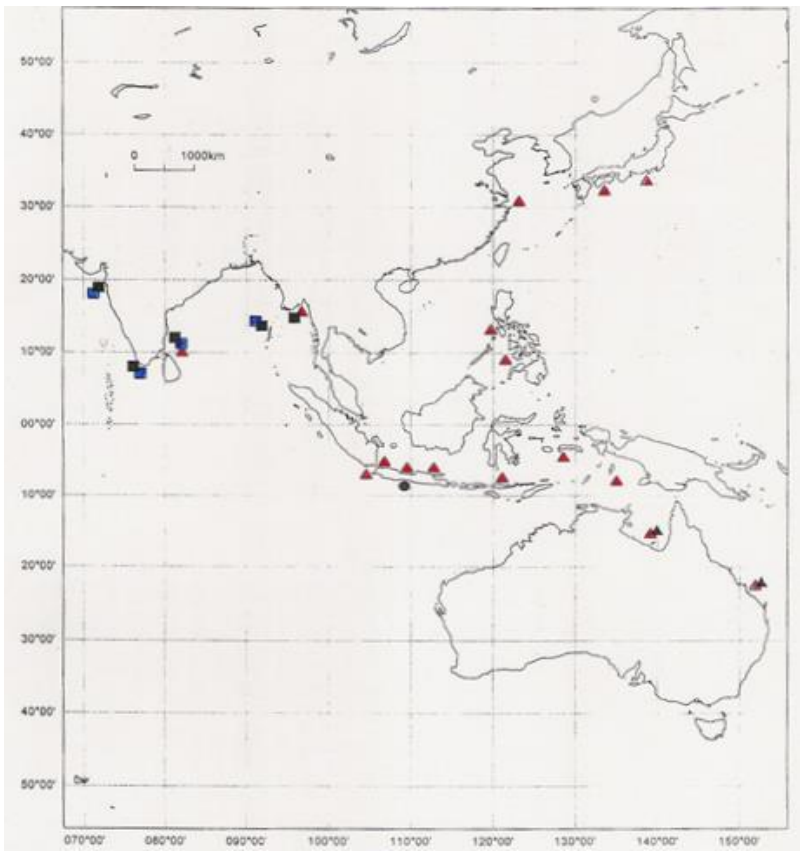

Fig. 3. Distribution of new species and published records of the Labidocera kroyeri group

$\boldsymbol{\Delta}=$ L. dakini Greenwood, $\mathbf{\Delta}=$ L. kroyeri (Brady), $\mathbf{\square}=$ L. gallensis Thomspon \& Scott, $\because=$ L. stylifera (Thomspon \& Scott), $\bullet=$ L. muranoi $\mathrm{n} . \mathrm{sp}$.

The characters of L. detruncata-group are 1) the posterior corners of prosome of both sexes protrude posteriorly into a pointed tip; 2) the female urosome is slightly or distinctly asymmetrical, about $1 / 6$ to 1.4 as long as prosome, and 2- or 3-segmented; 3 ) the rostrum of both sexes is widely divided; 4) the caudal rami of the female are slightly or remarkably asymmetrical, 
broadened, with or without one or more thickened setae; 5) the exopods of female P5 are asymmetrical, with each bearing three lateral and two terminal processes; 6) the endopods of female P5 are either simply conical (rarely bifid) distally or totally reduced; 7) the thumb of the right $\mathrm{P} 5$ of the male is conical or spatulate; 8 ) the finger of the right $\mathrm{P} 5$ of the male is slender; and 9) the terminal segment of the left P5 of the male bears one outer and three slender terminal (rarely thick in L. caudata) elements. Later, according to the author [10] divided all of the members of $L$. detruncata species group into five sub-species groups. Labidocera bataviae, L. detruncata, $L$. madurae and $L$. pavo clearly belong to the $L$. detruncata-group as the $L . d$. detruncata sub-group. Three Australian waters species, L. farrani, L. caudata and Labidocera sp., must be separated from the $L$. $d$. detruncata sub-group, in having 3-segmented urosomes, and Ri of P5 weakly bifid at the apex (as the L. d. farrani sub-group). Labidocera cervi and L. tasmanica have 3segmented urosomes with an elongated genital compound somite (as the L.d.cervi sub-group). The rest of species, L. jaafari and L. sinilobata have a 2segmented urosome and an elongated genital compound somite, Ri not fan-shaped with plumose caudal setae, and Ri of P5 absent (as the L. d. sinilobata sub-group). Labidocera kaimanaensis closely resembles members of the $L$. $d$. sinilobata sub-group in having those characters, except the urosome is 3-segmented (as the $L$. kaimanaensis sub-group).

The Labidocera minuta-group consists of only two species, L.bengalensis Krishnaswamy, and L. minuta. The characters of this group are 1) the urosome consists of 3 somites, Ur1 very elongated with many processes, 2) the Re of P5 long and slender, Ri very short and small, and 3) Pdg5 produced into rounded lobes. The male is identified by 1) the thumb of chela of P5 short, broader towards it tip with one medial process, 2) the right A1 with segment 17 armed with villiform denticulated ridges, fused segments 19-21 with blunt denticulate plate, segment 22 with long spur-like processes distally.

The Labidocera pectinata-group consists of nine species, i.e., L. carpentariensis, L. japonica, L. moretoni, L. muranoi, L. papuansis, L. pectinata, and L. rotunda (= L.bipinnata Tanaka, 1964). The characters of this group are 1) cephalic hooks present in both sexes of most species, 2) caudal rami in both sexes with $4^{\text {th }}$ innermost seta greatly elongated, about 1.5 or more times longer than adjacent setae, 3) Ur1 of female bearing one or more prominent lateral or dorsal processes or swellings, or with genital pore located ventrally at the distal end of segment, 4) male right A1: anterior border of segment 17 bearings unusual setiform process strongly bent at its base so that the portion distal end extends toward segment 18 , segment 18 with the proximal end of a denticulated ridge over reaching articulation with segment 17, segment 22 with distal spur, 5) male left P5: distal end of apical segment with two or more spiniform processes lateral to one or more aesthete-like processes, 6) male Pdg5 corners asymmetrical, right side larger and produced into one or more prominent sipinform processes, (7) male Ur1 distally with ventral or right lateral denticle or acicular process pointed posteriad.

Labidocera acuta and L. laevidentata are too diverse to be regarded as a species group (as an unassigned group). The differences occur in the position of cephalic hooks, the presence of median crest, segmentation of the antennule, and the shape and armature of the terminal segment of the right male fifth legs, and so on. However, the phylogenetic relationship of the genus Labidocera needs additional investigation by morphological and molecular analyses.

\section{Conclusion}

Indonesia is the country with the richest fauna of the family Pontellidae in terms of species and speciesgroups. In the present study 13 species of Labidocera were identified from nine sites of Indonesian coastal waters during 2003 to 2015. A mong these species, there were three new species, Labidocera javaensis, $L$. muranoi, and L. kaimanaensis, three new records, $L$. bengalensis, L. pavo, and L. sinilobata, and seven previously known species recorded from this area. The number of observed species was highest at eastern part with 11 recorded species. The Labidocera species records are decreased toward the coastal areas of Java Sea and Indian Sea side with 8 and 6 species, respectively.

A mong the Labidocera species discovered in this study, L. acuta, L. kroyeri, L. laevidentata, L. minuta and $L$. pavo are distributed in all study areas, $L$. bengalensis and $L$. javaensis are in A rea A-C, L. sinilobata is only in A rea $A, L$. muranoi is only in A rea $B$, and four species, $L$. bataviae, $L$. detruncata, L. kaimanaensis, and $L$. madurae are only in A rea $\mathrm{C}$, respectively.

Based on its morphological characters, these species are divided into five species-groups, detruncata-, kroyeri-, minuta-, pectinata-group, and an unassigned group. The Labidocera detruncata-group includes $L$. bataviae, L. detruncata, L. kaimanaensis, L.madurae, $L$. pavo, and L. sinilobata. The Labidocera kroyeri-group includes L. kroyeri, and L. muranoi. The Labidocera minuta-group includes $L$. bengalensis and L. minuta. The Labidocera pectinata-group includes $L$. javaensis, $L$. papuensis, and $L$. rotunda. The unassigned group includes $L$. acuta and $L$. laevidentata. Later the $L$. detruncata species-group can be divided into five species-subgroups, namely the $L$. detruncata cervi-, $L$. d.detruncata-, L. d. farrani-, L. d. kaimanaensis-, and $L$. d. sinilobata-subgroups. $T$ heir geographical range allopatric or parapatric and relatively short.

Based on their occurrence, geographic ranges, and habitats, one species, L. detruncata was cosmopolitan, while Indo-Pacific species comprised seven species of the total species number. One species each was found from either Indian or Pacific Oceans, L. bengalensis and $L$. sinilobata, respectively. The remaining three species appear to be endemic to Indonesian waters.

Based on their horizontal distribution and habitats, copepods are divided into five groups, oceanic, neriticoceanic, neritic, estuarine-neritic and estuarine. 
According to these groups, 11 species of the present species were classified as neritic species, and two species, $L$. acuta and $L$. laevidentata were neriticoceanic species.

\section{References}

1. J. Lubbock. Ann. Mag. Nat. Hist 11, 202-209 (1853)

2. G. A. Boxshall, S. H. Halsey. R. Soc. Lond 1-2, i-xv, 1-421, i-vii, 422-966 (2004)

3. A. Fleminger. UNESCO Tech. Pap. Mar. Sci 49, 8497 (1986)

4. A. Fleminger, B.H.R. Othman, J.G. Greenwood, J. Plankton Res 4, 246-270 (1982) DOI: $10.1093 /$ plankt/4.2.245

5. K. Sherman. J. Limnol Oceanogr 8, 214-227 (1963)

6. K. Sherman. J. Limnol Oceanogr 9: 476-484 (1964) https://doi.org/10.4319/1o.1964.9.4.0476

7. A. Scott, A. Siboga Exped. Monogr 29a, 1-323 (1909)

8. Mulyadi. Crustaceana 70(6), 653-675 (1997) https://doi.org/10.1163/156854097X00113

9. Mulyadi. Treubia 32, 1-167 (2002)

10. Mulyadi. Crustaceana 87(14), 1620-1639 (2014) DOI: $10.1163 / 15685403-00003375$

11. Mulyadi, Treubia 46, 73-84 (2019) DOI: 10.14203/treubia.v46i0.3793

12. R. Huys, G.A. Boxshall. London: Ray Society 159, $1-468(1991)$

13. D. Y. Kim. Taxonomical study on calanoid copepods (Crustacea: Copepoda) in Korean waters: 1-187, 50 pls. Thesis: Hanyang Univ. Korea (1985)

14. M. Madhupratap, P. Haridas, Oceanol. Acta 9(2), 105-117 (1986)

15. E.G. Silas, P. Pillai. J. mar. biol. Ass. India 15(2), 771-858 (1973)

16. J. G. Greenwood, B.H.R. Othman. J. Plankton Res 1, 231-239 (1979)

17. H.B. Owre, M. Foyo. Copepods of the Florida Current. Fauna Caribbean number 1. Crustacea, part 1: Copepoda, 1-137 (University of Miami, Miami, 1967 )

18. M. M. El-Sherbiny. Some ecological studies on zooplankton in Sharm El-Sheikh (Red Sea). MSc. thesis Ismailia: Suez Canal University (1997)
19. M. M. El-Sherbiny, H. Ueda. Org. Divers. Evol 10, 23-29. (2010)

20. Y. Halim. Annual Review of Oceanography and Marine Biology 7, 231-275 (1969)

21. S. Krishnaswamy. J. Madras Univ 23, 107-144 (1952)

22. I.C. Thompson, A. Scott. Report on the Copepoda collected by Prof. Herdman at Ceylon 7 (Rep. Gov.Ceylon Pearl Oyster Fisheries, 1903)

23. T. Mori, The pelagic Copepoda from the neighbouring waters of Japan (Soyo Co. Inc, Tokyo, 1937)

24. G. S. Brady. Zool 8, 1-142 (1883)

25. J. M. Bradford-Grieve. Mem. N.Z. Oceanogr. Inst 111, 1-266 (1999)

26. Q. C. Chen, S. Z. Zhang. Stud. Mar. Sin 7, 20-131. (in Chinese with English summary) (1965)

27. Q. C. Chen. Proc. $2^{\text {nd }}$ Intern. Copepoda, Ottawa, Canada, 524-529 (1984)

28. W. J. Dakin, A. N. Colefax. Publs. Univ. Sydney Dep. Zool. 1-211(1940)

29. G. P. Farran. Sci Rep. Gt. Barrier Reef Exped 5, 73142 (1936)

30. W. Giesbrecht. Systematik und faunistic der pelagischencopepoden des Golfes von Neaple, Fauna und Flora des Golfes von Neapel und der angrenzenden Meeresabschnitte, 1-831, 54 pls. (1892)

31. J. G. Greenwood. J. Nat. Hist 12, 536-543 (1978)

32. J. G. Greenwood. Proc. R. Soc. Queensland 90, 93111(1979)

33. H.G. Jeong, H.P.Suh, S.B. Jeong, Y.H. Yoon, H.Y. Soh. Zoological Studies 48(4), 508-523 (2009)

34. A. Kramer. Trans. N.Z. Inst 21, 214-223 (1895)

35. A.D McKinnon, W.J. Proc. R. Soc. Vict 96 (3), 169172 (1984)

36. A.C. Nicholls. Rec. S. Aust. Mus 8, 1-62 (1944)

37. B.H.R Othman. Malay. Nat. J 39, 193 -201 (1986)

38. I. Prusova, F. Al_Yamani. Crustaceana 87(10), 11491167 (2014)

39. R.B.S Sewell. Mem. Indian Mus 10, 1- 407 (19291932)

40. O. Tanaka. J. Seto mar. biol. Lab 12: 231-271(1964)

41. Taw, Nyan. J. mar. Frehwat. Res 25, 261-272 (1974)

42. C.B. Wilson. U.S. natn. Mus. Bull 100(14), 141-441 (1950) 